\title{
Carbon and Nitrogen Stock Under Different Types of Land Use in a Seasonally Dry Tropical Forest
}

\author{
W. Valbrun ${ }^{1}$, E. M. de Andrade ${ }^{1}$, A. M. M. de Almeida ${ }^{1}$ \& E. L. de Almeida ${ }^{1}$ \\ ${ }^{1}$ Universidade Federal do Ceará, Fortaleza, CE, Brazil \\ Correspondence: A. M. M. de Almeida, Universidade Federal do Ceará, Fortaleza, CE, Brazil. E-mail: \\ ald_m_m@hotmail.com
}

Received: September 5, 2018

Accepted: October 5, $2018 \quad$ Online Published: November 15, 2018

doi:10.5539/jas.v10n12p479

URL: https://doi.org/10.5539/jas.v10n12p479

\begin{abstract}
The aim of this study, was to analyse the effect of cover vegetation change on stocks of Total Organic Carbon (ST.TOC) and Total Nitrogen (ST.TN) in soils of a Seasonally Dry Tropical Forest in the Brazilian semi-arid region. The study was carried out on three farms located on a typical Orthic Chromic Luvisol in an SDTF. Soil samples were collected from trenches, $70 \times 70 \mathrm{~cm}$ in size, in the 0-10, 10-20, 20-30, 30-40, 40-60 and 60-80 cm layers, under four types of land use: dense Caatinga (DC), open Caatinga (OC), agriculture (AG) and pasture (PA). The following attributes were evaluated: bulk density, Total Organic Carbon (TOC), Total Nitrogen (TN), ST.TOC and ST.TN. The data were compared using the Mann-Whitney test $(\mathrm{p} \leq 0.05)$. Hierarchical Grouping Analysis (HGA) was used to understand the behaviour of the attributes evaluated between cover vegetation types. Using HGA resulted in the formation of three distinct groups for the types of land use under investigation. The highest mean values for ST.TOC (11.29 Mg ha ${ }^{-1}$ ) and ST.TN (3.36 Mg ha $\left.{ }^{-1}\right)$ were found in CD and CA. The changes in land use in the SDTF had an effect on ST.TOC and ST.TN. It is therefore necessary to adopt strategies and strengthen conservation practices in areas of agricultural and pasture, and reduce the process of degradation and further the process of recovery in these areas. Such action will reduce the loss of $\mathrm{C}$ and N, and increase the levels and stocks of TOC and TN.
\end{abstract}

Keywords: Caatinga biome, semi-arid region, stocks

\section{Introduction}

In the context of global climate change, the focus is on the soil and different forms of use and management (Costa et al., 2009), especially as the soil can be a source or sink of atmospheric $\mathrm{CO}_{2}$ (Carvalho et al., 2009) depending on the type of management adopted. Anthropogenic activity has caused a rise in the concentration of greenhouse gases (GHG) in the atmosphere, including $\mathrm{CO}_{2}$. Among the major anthropogenic causes of increased $\mathrm{CO}_{2}$ concentrations are the use of fossil fuels, deforestation and changes in land-use (Ghommem et al., 2012; Li, 2014).

In Brazil, $\mathrm{CO}_{2}$ emissions from land use and farming are very pronounced, representing about $52 \%$ of the total emissions in 2012 (MTC, 2014). In the State of Minas Gerais, deforestation and changes in land use account for $54 \%$ of greenhouse gas emissions (Brazil, 2010). For this reason, study of the carbon cycle is becoming increasingly necessary, especially in little-known biomes, such as Tropical Seasonally Dry Forests (SDTF), Caatinga.

The changes occurring in the Caatinga biome, historically due to the absence of soil-conservation techniques, have contributed to modify the biogeochemical cycling of carbon and nitrogen two elements of great importance, directly associated with the greenhouse effect and climate change (Araújo Filho, 2013).

Changes in land use and occupation in the Brazilian semi-arid region, where the SDTF (Caatinga) is located, have led to the degradation of natural resources, especially a decline in soil fertility. According to Sacramento (2013), the Caatinga is possibly a significant carbon sink that is still little known or exploited, considering the unique characteristics of the vegetation and climate. Conventional management of agricultural systems, together with low biomass production in the Caatinga, has helped to reduce stocks of carbon and nitrogen in the soil of the semi-arid region (Sacramento, 2013). The input of carbon to the semi-arid environment through photosynthesis depends primarily on the type of ground cover and land use, as both directly influence the amount of organic waste and microbial activity in the soil. 
The biome is being deforested hurriedly, illegally and unsustainably for the production of energy and biomass, whether for domestic or industrial purposes, the production of pasture (overgrazing), and/or other agricultural uses (MMA, 2014). Deforestation and forest burning contribute to increasing the greenhouse effect, as they release $\mathrm{CO}_{2}$ into the atmosphere; however, with conservation actions and the planting of forests, the reverse effect occurs due to the appearance of carbon sinks, since forests remove part of the $\mathrm{CO}_{2}$ (Silva et al., 2008).

According to Souza (2012), the Caatinga has a high potential for storing carbon in the soil and the debris from the aerial parts of the trees (litter), and shows varying increases in this stock depending on the period of seasonal rainfall. Management of the carbon and nitrogen stored under the various types of Caatinga management is an indication that preserved vegetation, or vegetation in the process of restoration, has the potential to assimilate and retain carbon. Research to determine the stocks of $\mathrm{C}$ and $\mathrm{N}$ in soils of the Brazilian semi-arid region is still in the early stages (Aquino et al., 2017; Sampaio \& Costa, 2011).

In agricultural systems, the total stock of organic carbon in the soil (TOC) is often influenced by the type of management adopted, since changes in land use, especially the replacement of native forests by areas of agriculture or pasture and vice versa, cause changes in the stocks of carbon and nitrogen in the soil. These changes depend on the type of land use and the management practices employed (MCT, 2010). In agricultural areas, $\mathrm{CO}_{2}$ is released when burning plant residue and when turning the soil, since with the greater input of oxygen, the mineralisation and oxidation of organic matter increases (Rosendo et al., 2012).

Areas with a predominance of native vegetation have a greater stock of plant biomass than areas of open pasture or areas planted with short-cycle crops, with a similar pattern for carbon stored in the soil (Sampaio \& Costa, 2011); however Aquino et al. (2017) showed that thinning, and adoption of the correct type of management, promotes an increase in the total organic carbon and total nitrogen content. The hypothesis therefore, is that the soils of a Seasonally Dry Tropical Forest (Caatinga) have different stocks of carbon and nitrogen pending on land use. An understanding of the storage capacity of organic carbon and total nitrogen in their various compartments and their quantification under different management regimes is therefore of fundamental importance. Due to the importance of the issues addressed, the aim of this study was to analyse the effect of changes in vegetation type (dense Caatinga, open Caatinga, agriculture and pasture) on the stocks of TOC and TN in the soil of a Seasonally Dry Tropical Forest (Caatinga).

\section{Material and Methods}

\subsection{Location and Description of the Experimental Areas}

The research was carried out in three parts of the cities of Pentecost (FEVC), Piquet Carneiro (PC) and Quixadá (QD) in the interior of the State of Ceará, Brazil (Figure 1, Table 1). Areas of dense Caatinga (DC), open Caatinga $(\mathrm{OC})$, agriculture $(\mathrm{AG})$ and pasture $(\mathrm{PA})$ were chosen on each farm.
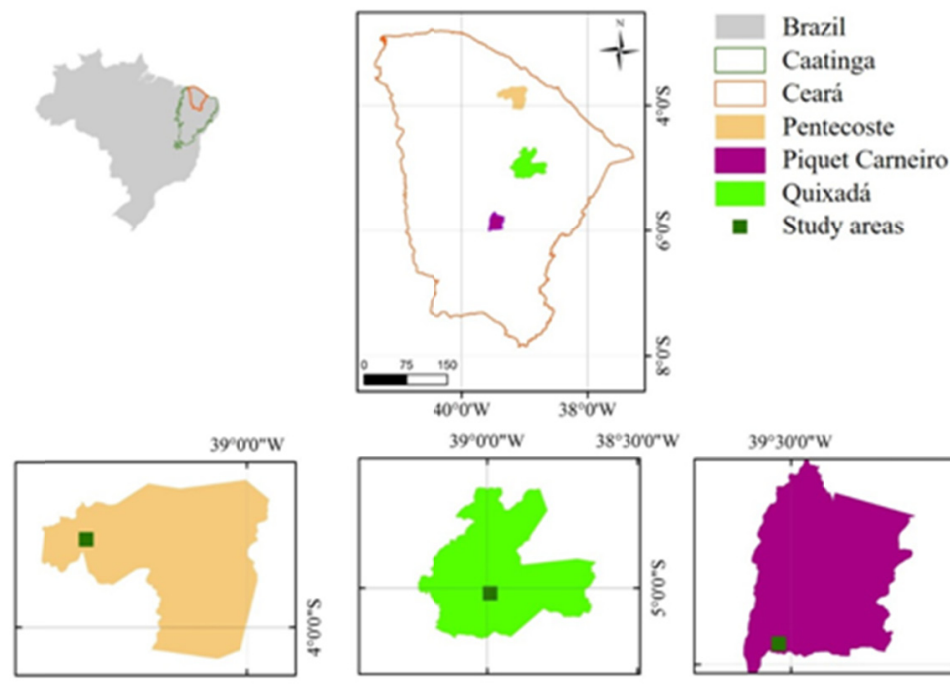

Figure 1. Location of the farms under study 
According to the Koppen classification, the climate in the region is of type BSh', and belongs to the group of a warm and semi-arid climate, with average annual temperatures always above $18{ }^{\circ} \mathrm{C}$. The rainfall regime in the northeastern semi-arid region, which includes the State of Ceará, is characterised by the uncertainty of the rainfall events and not by the total precipitation. The annual average (around $750 \mathrm{~mm}$ ) surpasses many regions of the world (Andrade et al., 2017). The rainy season lasts from two to three months, rarely exceeding four months (Pereira et al., 2016).

The vegetation is dense shrub-like Caatinga, closed shrub-like Caatinga and thorny deciduous forest, with the presence of cacti and undergrowth. The predominant vegetation in the areas is woody, with the possible presence of herbaceous species. A description of land use on the three farms is shown in Table 1.

Table 1. Description of land use

\begin{tabular}{|c|c|c|c|c|}
\hline Land use & Farm & Coordinates & Description of land use & Photos used \\
\hline \multirow{3}{*}{ Dense Caatinga } & Pentecoste & $\begin{array}{l}3^{\circ} 48^{\prime} 19^{\prime \prime} \mathrm{S} \\
39^{\circ} 21^{\prime} 03^{\prime \prime} \mathrm{W}\end{array}$ & $\begin{array}{l}\text { This has always been an area of Caatinga, } \\
\text { goats pass through the area and there are signs } \\
\text { of wood being removed. }\end{array}$ & \\
\hline & Piquet Carneiro & $\begin{array}{l}3^{\circ} 48^{\prime} 19^{\prime \prime} \mathrm{S} \\
39^{\circ} 21^{\prime} 03^{\prime \prime} \mathrm{W}\end{array}$ & $\begin{array}{l}\text { Closed Caatinga with stony characteristics and } \\
\text { rocks on the surface. }\end{array}$ & \\
\hline & Quixadá & $\begin{array}{l}5^{\circ} 01^{\prime} 24^{\prime \prime} \mathrm{S} \\
38^{\circ} 59^{\prime} 32^{\prime \prime} \mathrm{W}\end{array}$ & $\begin{array}{l}\text { Comprises areas with completely closed, } \\
\text { natural vegetation under regeneration for more } \\
\text { than } 30 \text { years. }\end{array}$ & \\
\hline \multirow{3}{*}{ Open Caatinga } & Pentecoste & $\begin{array}{l}3^{\circ} 48^{\prime} 56^{\prime \prime} \mathrm{S} \\
39^{\circ} 20^{\prime} 50^{\prime \prime} \mathrm{W}\end{array}$ & $\begin{array}{l}\text { Area with some burned tree trunks, showing } \\
\text { evidence of anthropogenic action. }\end{array}$ & \\
\hline & Piquet Carneiro & $\begin{array}{l}3^{\circ} 48^{\prime} 39^{\prime \prime} \mathrm{S} \\
39^{\circ} 20^{\prime} 57^{\prime \prime} \mathrm{W}\end{array}$ & $\begin{array}{l}\text { Natural vegetation under regeneration for } \\
10-15 \text { years. }\end{array}$ & \\
\hline & Quixadá & $\begin{array}{l}5^{\circ} 00^{\prime} 58^{\prime \prime} \mathrm{S} \\
38^{\circ} 59^{\prime} 23^{\prime \prime} \mathrm{W}\end{array}$ & $\begin{array}{l}\text { Naturally open Caatinga with signs of } \\
\text { anthropogenic action (removal of wood). } \\
\text { Caatinga very disturbed. }\end{array}$ & \\
\hline
\end{tabular}




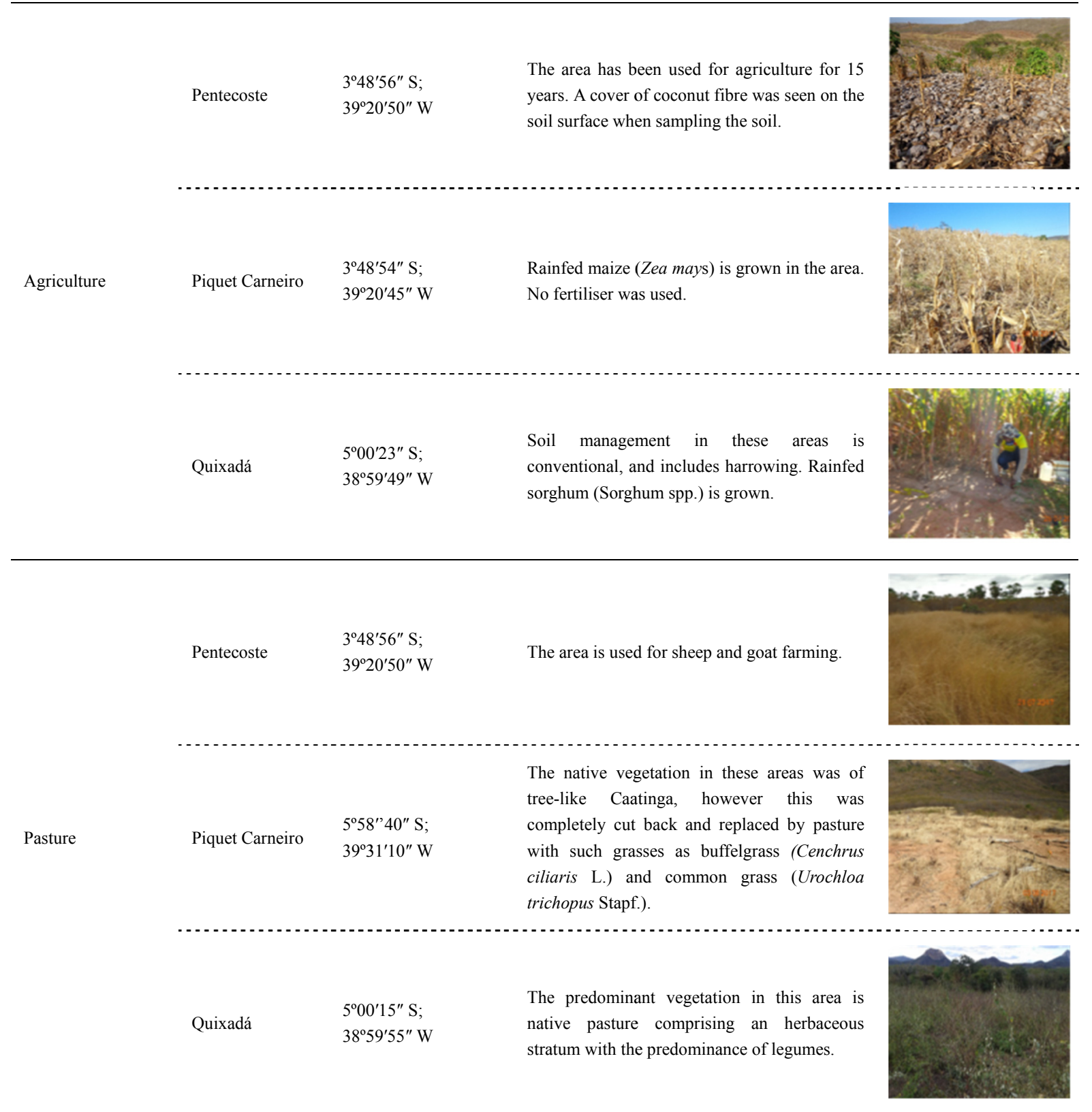

The soil of the four types of land use was classified as a typical Orthic Chromic Luvisol according to the Brazilian System of Soil Classification (EMBRAPA, 2013). 
Table 2. Characterisation of the physical and chemical attributes of the studied soil under different types of land use in the semi-arid region of Ceará, Brazil

\begin{tabular}{|c|c|c|c|c|c|c|c|c|c|c|c|c|}
\hline \multicolumn{13}{|c|}{ Physical characterisation } \\
\hline \multirow{2}{*}{ Horizon } & \multirow{2}{*}{ Depth } & & \multicolumn{6}{|c|}{ Granulometric composition } & \multirow{2}{*}{\multicolumn{2}{|c|}{ atio Silt/Clay }} & \multirow{2}{*}{\multicolumn{2}{|c|}{ Textural class }} \\
\hline & & & \multicolumn{2}{|l|}{ Sand } & \multicolumn{2}{|l|}{ Silt } & \multicolumn{2}{|c|}{ Clay } & & & & \\
\hline & \multicolumn{2}{|l|}{$\mathrm{cm}$} & \multicolumn{10}{|c|}{ - - } \\
\hline A & \multicolumn{2}{|l|}{$0-10$} & \multicolumn{2}{|l|}{84.5} & \multicolumn{3}{|c|}{10.6} & \multicolumn{3}{|c|}{2.2} & \multicolumn{2}{|c|}{ Loamy sand } \\
\hline $\mathrm{AB}$ & \multicolumn{2}{|l|}{$10-20$} & 77.6 & \multicolumn{2}{|r|}{12.7} & \multicolumn{2}{|c|}{9.7} & \multicolumn{3}{|c|}{1.3} & \multicolumn{2}{|c|}{ Sandy loam } \\
\hline Bt1 & \multicolumn{2}{|l|}{$20-50$} & 70.7 & \multicolumn{2}{|r|}{13.7} & \multicolumn{2}{|c|}{15.6} & \multicolumn{3}{|c|}{0.9} & \multicolumn{2}{|c|}{ Sandy loam } \\
\hline Bt2 & \multicolumn{2}{|l|}{$50-80+$} & 49.8 & \multicolumn{2}{|r|}{24.2} & \multicolumn{2}{|c|}{26.1} & \multicolumn{3}{|c|}{0.9} & \multicolumn{2}{|c|}{ Clayey sandy loam } \\
\hline \multicolumn{13}{|c|}{ Chemical characterisation } \\
\hline \multirow{2}{*}{ Horizon } & $\mathrm{pH}\left(\mathrm{H}_{2} \mathrm{O}\right)$ & \multicolumn{8}{|c|}{ Sorption complex } & \multirow{2}{*}{$\mathrm{V}$} & & \\
\hline & $1: 2.5$ & $\mathrm{Ca}^{2+}$ & $\mathrm{Mg}^{2+}$ & $\mathrm{K}^{+}$ & $\mathrm{Na}^{+}$ & $\mathrm{S}$ & $\mathrm{Al}^{3+}$ & $\mathrm{H}^{+}$ & CEC & & $\mathrm{M}$ & PES \\
\hline & & $+----\cdot$ & ----- & 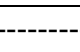 & $-\mathrm{cmol}$ & $\mathrm{kg}^{-1}--$ & 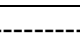 & ----- & -------- & ------ & ----- \% & ------- \\
\hline A & 5.67 & 3.30 & 1.60 & 0.10 & 0.04 & 5.03 & 0.10 & 0.50 & 5.63 & 89.35 & 1.95 & 0.63 \\
\hline $\mathrm{AB}$ & 5.46 & 1.60 & 1.10 & 0.14 & 0.04 & 2.88 & 0.10 & 2.00 & 4.98 & 57.84 & 3.35 & 0.89 \\
\hline Bt1 & 5.90 & 1.80 & 1.20 & 0.14 & 0.05 & 3.19 & 0.10 & 1.10 & 4.39 & 72.66 & 3.04 & 1.18 \\
\hline $\mathrm{Bt} 2$ & 5.90 & 3.50 & 1.60 & 0.10 & 0.19 & 5.39 & 0.10 & 0.70 & 6.19 & 87.07 & 1.82 & 3.04 \\
\hline
\end{tabular}

A class of shallow soils with little depth (Table 2), typical of the semi-arid environment, rich in bases and with high-activity clay, presenting an accumulation of clay in the subsurface, with a predominance of group 2:1 expansive clay minerals, especially montmorillonite, and characterised by a Bt horizon (Santos et al., 2013).

\subsection{Soil Sampling and Collection}

The soil samples in the three farms under study (FEVC, PC and Quixadá) for each type of land use DC, OC, AG and PA, were collected from 12 trenches, ( 3 farms $\times 4$ types of land use and 1 class of soil), with each site considered a replication. The criteria for selecting the study are were the presence of the Caatinga biome and the most representative class of soil in each area. The sampling points were georeferenced using GPS equipment, where the altitude, relief and drainage of the landscape were taken into account. The soil in the trenches was collected with the aid of a Dutch auger.The samples were collected from the 0-10, 10-20, 20-30, 30-40, 40-60 and $60-80 \mathrm{~cm}$ layers. The trenches were $70 \times 70 \mathrm{~cm}$ in size in the four types of land use CD, CA, AG and PA on the three farms under study. Undisturbed samples (in triplicate) and disturbed samples were collected in the trenches for density and chemical analysis respectively. The samples were packed in labelled plastic bags, which were closed and sent to the Soil Management Laboratory of the Federal University of Ceará. The undisturbed soil samples were removed with the aid of metal rings using cylinders $5.7 \mathrm{~cm}$ in diameter and $5.3 \mathrm{~cm}$ in height, and dried in an oven at $105^{\circ} \mathrm{C}$ for 72 hours. The disturbed soil samples (still in the field) were passed through a $4 \mathrm{~mm}$ sieve to eliminate coarse rocks and plant material. They were then air-dried, macerated and passed through a $2 \mathrm{~mm}$ sieve.

\subsection{Analytical Determination}

\subsubsection{Physical Soil Analysis}

Bulk density (Ds) was determined by the volumetric ring method (Black et al., 1965) Quantification of the clay fraction was by the pipette method, the sand fraction by sifting, and the silt fraction by the difference between the total sample of fine soil dried in a hothouse and the sum of sand and clay (Black et al., 1965). 1N sodium hydroxide $(\mathrm{NaOH})$ was used for chemical dispersion of the particles.

\subsubsection{Chemical Soil Analysis}

Soil $\mathrm{pH}$, exchangeable acidity $\left(\mathrm{Al}^{3+}\right)$, potential acidity $\left(\mathrm{H}^{+}+\mathrm{Al}^{+3}\right)$ and components of the Sorption Complex $(\mathrm{Na}$, $\mathrm{K}^{+}, \mathrm{Ca}, \mathrm{Mg}$ ) were determined as per the method Black et al. (1965). From this data, the cation exchange capacity (CEC) at pH 7 (Black et al., 1965), and the percentage of base saturation (V\%) were calculated. The total organic carbon (TOC) content was determined by wet oxidation of $0.167 \mathrm{~mol} \mathrm{~L}$-1 potassium dichromate $\left(\mathrm{K}_{2} \mathrm{Cr}_{2} \mathrm{O}_{7}\right)$ in acidic medium $\left(\mathrm{H}_{2} \mathrm{SO}_{4}\right)$ with an external heat source, using a digestion block at $170{ }^{\circ} \mathrm{C}$ for 30 min. After oxidation, the excess dichromate was titrated with $0.2 \mathrm{~mol} \mathrm{~L}-1$ ammonium ferrous sulphate solution $\left(\mathrm{Fe}\left(\mathrm{NH}_{4}\right)_{2}\left(\mathrm{SO}_{4}\right)_{2} \cdot 6 \mathrm{H}_{2} \mathrm{O}\right)$ following the method described by Yeomans and Bremner (1988). The Total Nitrogen (TN) in the soil was 
determined by sulphuric acid digestion, followed by Kjeldahl distillation and titration with $0.02 \mathrm{~mol} \mathrm{~L}^{-1} \mathrm{HCL}$ (Black et al., 1965)

The stocks of TOC and TN were obtained by soil mass correction, using the thickness of the soil layer and the equivalent soil mass by means of the reference soil mass (Ellert et al., 2001 apud Demessie et al., 2013 ). In calculating the equivalent mass, the relative soil mass was considered for the different types of land use in Equation 1:

$$
\text { Msoil }=D s \times T \times A
$$

where, Msoil $=$ soil mass per unit area $\left(\mathrm{Mg} \mathrm{ha}^{-1}\right)$; Ds $=$ bulk density in the layer $\left(\mathrm{Mg} \mathrm{m}^{-3}\right) ; \mathrm{T}=$ thickness of soil layer (m); $\mathrm{A}=$ unit area, in this case, 1 ha $\left(10,000 \mathrm{~m}^{2}\right)$.

After the soil mass was defined, the dense Caatinga was considered as reference area, and the additional thickness calculation was performed; this calculates the thickness value to be added or subtracted from the different types of land use in relation to the reference thickness (Ellert et al., 2001). Equation 2 shows the formula for calculating the added or subtracted thickness value:

where:

$$
\frac{\text { Tadd }}{\text { sub }}=(\text { Mref }- \text { Marea }) \times \frac{\text { fha }}{\text { dsarea }}
$$

Tadd $/$ sub $=$ soil thickness of the layer to be added $(+)$ or subtracted $(-)(\mathrm{m})$; Mref. = equivalent soil mass of the reference treatment $\left(\mathrm{Mg} \mathrm{ha}^{-1}\right)$; Marea $=$ equivalent soil mass of the area $\left(\mathrm{Mg} \mathrm{ha}^{-1}\right)$; fha $=$ conversion factor from ha to $\mathrm{m} 2\left(0.0001 \mathrm{ha} \mathrm{m}^{-2}\right)$; dsarea $=$ bulk density of the area in the layer $\left(\mathrm{Mg} \mathrm{m}^{-3}\right)$;

With the values for soil mass and the thickness to be added or subtracted, the stocks of TOC and TN were calculated using Equations 3 and 4:

$$
\begin{aligned}
& \text { Stock } \cdot(T O C)=T O C \times D s\left(T \pm \frac{T a d d}{s u b}\right) \times A \times F k g \times F G s \\
& \text { Stock } \cdot(T N)=T N \times D s\left(T \pm \frac{T a d d}{\text { sub }}\right) \times A \times F k g \times F G s
\end{aligned}
$$

Stock $(T O C)=$ total organic carbon stock at a given depth $\left(\mathrm{Mg} \mathrm{ha}^{-1}\right)$; Stock $(T N)=$ total soil $\mathrm{N}$ stock at a given depth $\left(\mathrm{Mg} \mathrm{ha}{ }^{-1}\right) ; T O C=$ Total Organic Carbon content ( $\mathrm{g} \mathrm{kg}^{-1}$ soil); $T N=$ Total Nitrogen content $\left(\mathrm{g} \mathrm{kg}^{-1}\right.$ soil); Ds $=$ bulk density in the layer $\left(\mathrm{g} \mathrm{cm}^{-3}\right) ; T=$ thickness of the soil layer $(\mathrm{m})$; Tadd/sub = thickness of the soil layer to be added $(+)$ or subtracted $(-)(\mathrm{m}) ; \mathrm{A}=$ unit area, in this case, 1 ha $\left(10,000 \mathrm{~m}^{2}\right) ; \mathrm{Fkg}=$ conversion factor $\mathrm{kg}$ to $\mathrm{Mg}$ $\left(0.001 \mathrm{Mg} \mathrm{ha}^{-1}\right) ; \mathrm{FGs}=$ stoniness factor $(1-(\%$ gravel 100)).

The percentage (\%) of gravel (Equation 5) was calculated by dividing the weight of the gravel by the total weight in each soil layer, adopting the methodology proposed by Donagena et al. (2011):

$$
\text { Gravel } \cdot(\%)=\frac{\text { Mgravel }}{\text { Mtotal }} \times 100
$$

Mgravel $=$ Weight of gravel in the layer $(\mathrm{Mg}$ ha-1); Mtotal $=$ Weight of the soil + weight of gravel in the layer $(\mathrm{Mg}$ $\left.\mathrm{ha}^{-1}\right)$.

After grouping, the weighted mean values for ST.TOC and ST.TN were determined with the following equations (6 and 7):

$$
\begin{gathered}
\text { Stock } \cdot(\text { TOC })=\frac{\sum_{n-1}^{n}(T O C) \times D S\left(T \pm \frac{T a d d}{s u b}\right) \times A \times F k g \times F G s}{n} \\
\operatorname{Stock} \cdot(T N)=\frac{\sum_{n-1}^{n}(T N) \times D S\left(T \pm \frac{\text { Tadd }}{\text { sub }}\right) \times A \times F k g \times F G s}{n}
\end{gathered}
$$

where, $n$ : represents the number of cases in each group under evaluation.

\subsection{Statistical Analysis}

The experimental design was a system of subdivided plots. The main treatments (plots) consisted of four types of management (CD, CA, AG and PA), and the secondary treatments comprised the depths $(00-10 \mathrm{~cm}, 10-20 \mathrm{~cm}$, $20-30 \mathrm{~cm}, 30-40 \mathrm{~cm}, 40-60 \mathrm{~cm}$ and $60-80 \mathrm{~cm}$ ). The data were submitted to the Shapiro-Wilk test for normality. As the data did not present a normal distribution, the Mann-Whitney non-parametric test of means was used at 5\% significance, with the dense Caatinga taken as reference compared to the other types of land use. 
In order to verify similarity of the class for each type of land use, the soil attributes (stock.TOC and stock.TN) were grouped using the technique of Multivariate Analysis/Hierarchical Group Analysis (HGA). For the group analysis, the data were transformed and standardised to avoid interference from the different units of measure and different scales. All the statistical analyses were carried using the Statistical Package for the Social Sciences (SPSS) software, version 16.0, and the figures produced using the SigmaPlot software.

\section{Results}

\subsection{Apparent Bulk Density}

Below $10 \mathrm{~cm}$ in depth, the mean values for density $\left(\mathrm{g} \mathrm{cm}^{-3}\right)$ tend to increase gradually (Figure 2).

A significant difference $(\mathrm{p}<0.05)$ was seen between the dense Caatinga (DC), open Caatinga $(\mathrm{OC})$ and agriculture $(\mathrm{AG})$ in the 10-20, 30-40 and 60-80 cm layers (Figure 2). In the area of PA, it was found that the apparent densities in the 0-10 and 10-20 cm layers were higher when compared to DC, with the apparent density in PA showing mean values of 1.09 to $1.21 \mathrm{~g} \mathrm{~cm}^{-3}$ in the first and second layers respectively; whereas in DC, the values for soil density were from 0.97 to $1.05 \mathrm{~g} \mathrm{~cm}-3$ for the first two layers. Further, in the $40-60 \mathrm{~cm}$ layer, the values for apparent density in PA were higher than in DC (Figure 2). The highest apparent density was recorded for AG, when compared to DC in the $0-10,10-20,20-30,30-40$ and $60-80 \mathrm{~cm}$ layers, the exception being the $40-60 \mathrm{~cm}$ layer.

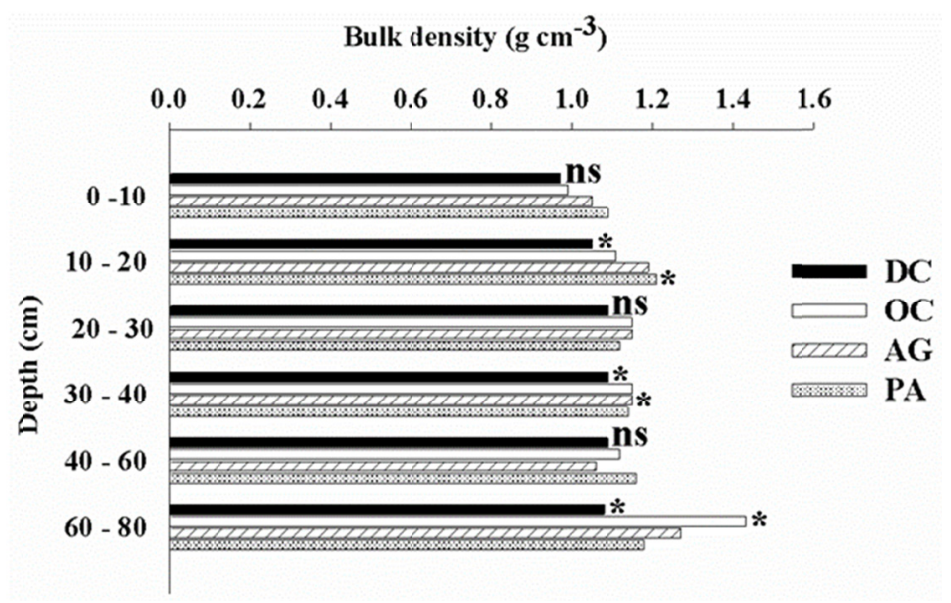

Figure 2. Bulk density by layer under different systems of land use in the semi-arid region of Ceará. Dense Caatinga (DC); Open Caatinga (OC); Agriculture (AG) and Pasture (PA). An asterisk ${ }^{*}$ ) shows a significant difference $(\mathrm{p}<0.05)$ between the types of land use when compared to DC in the same layer. ${ }^{\text {ns }}$ do not differ statistically. The Mann-Whitney test was applied at a level of 5\%. Dense Caatinga (DC); Open Caatinga (OC);

Pasture (PA); Agriculture (AG)

\subsection{TOC Content}

The highest levels of TOC were identified in the surface layers, decreasing with depth in all the types of land use being investigated (Figure 3). Irrespective of land use, the TOC content ranged from $1.87 \mathrm{~g} \mathrm{~kg}^{-1}$ to $14.17 \mathrm{~g} \mathrm{~kg}^{-1}$ in the 0-10, 10-20, 20-30, 30-40, 40-60 and 60-80 cm layers (Figure 3). DC displayed higher levels of TOC, which differed statistically $(* p<0.05)$ in the $0-10,10-20,20-30$ and $60-80 \mathrm{~cm}$ layers for AG, PA and OC respectively (Figure 3). However, in the 30-40 and 40-60 cm layers, there was no significant difference between the types of land use. The highest levels of TOC were found in the areas of DC and OC, and the lowest in AG. 


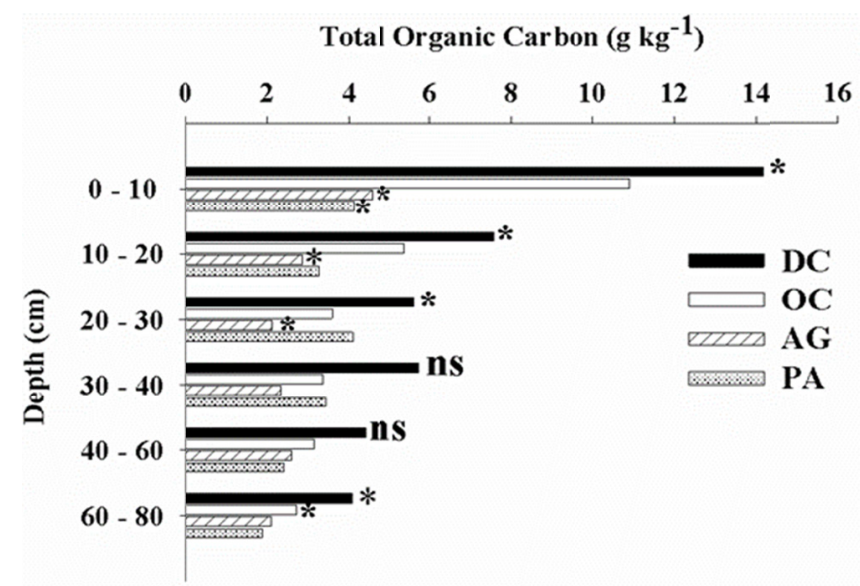

Figure 3. TOC content for different types of land use in a SDTF in the semi-arid region of Ceará, Brazil: An asterisk $(*)$ shows a significant difference $(\mathrm{p}<0.05)$ between types of land use when compared to DC in the same layer. ${ }^{\text {ns }}$ do not differ statistically. The Mann-Whitney test was applied at a level of $5 \%$. Dense Caatinga

(DC); Open Caatinga (OC); Pasture (PA); Agriculture (AG)

\subsection{TN Content}

The pattern for TN content was similar to that of the TOC content for each type of land use, with a reduction for increasing depth (Figure 4).

The types of land use showed no significant differences in the 10-20 and 20-30 cm layers (Figure 4); however, a significant difference $(p<0.05)$ was found between the types of land use in the 0-10, 30-40, 40-60 and 60-80 cm layers, where DC had the highest values for TN. The highest levels of TN were found in DC and OC in the 0-10, 10-20, 30-40 and 40-60 cm layers, when compared to AG and PA.

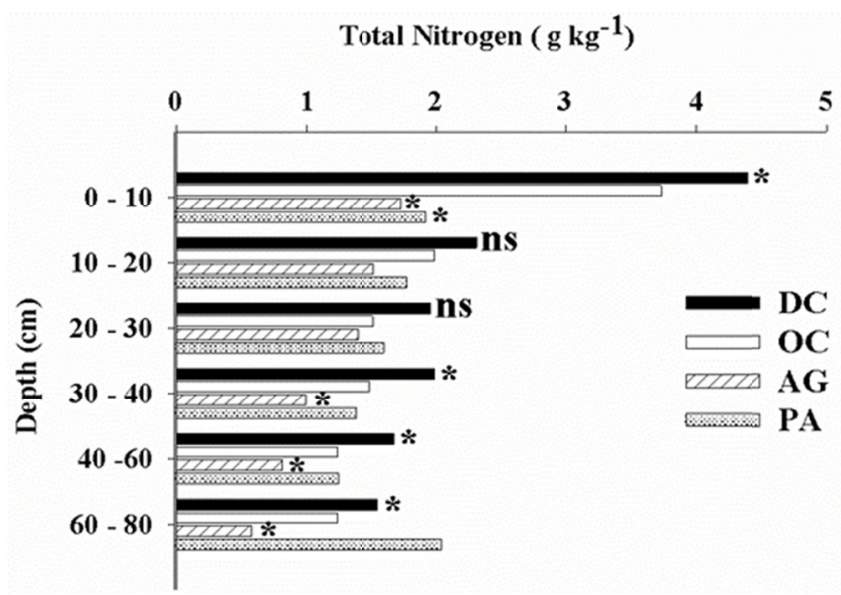

Figure 4. TN content for different types of land use in a SDTF in the semi-arid region of Ceará, Brazil: An asterisk $(*)$ shows a significant difference $(p<0.05)$ between types of land use when compared to DC in the same layer. ${ }^{\text {ns }}$ do not differ statistically. The Mann-Whitney test was applied at a level of 5\%. Dense Caatinga (DC); Open Caatinga (OC); Pasture (PA); Agriculture (AG)

\subsection{Stocks of TOC and TN}

Using HGA, it was possible to identify a similarity in the studied attributes between the types of land use. In order to minimise human influence in defining the number of similar groups.

In a visual analysis of the dendrogram (Figure 5), the cut-off point defined by the rescaled distance was confirmed, with the formation of three groups. The first group consisted of four cases derived from the combination of land use and depth (DC 20-30, DC 30-40, OC 10-20 and DC 10-20 cm); the second group was composed of 18 cases 
(AG 30-40, AG 40-60, AG 60-80, OC 20-30, OC 30-40, PA 40-60, AG 10-20, PA 40-60, OC 60 -60, OC 40-60, AG 20-30, PA 20-30, DC 60-80, AG 0-10, DC 40-60, PA 0-10, PA 10-20 and PA 60-80 cm) and the third group comprised 2 cases (DC 0-10 and OC 0-10 cm) (Figure 5).

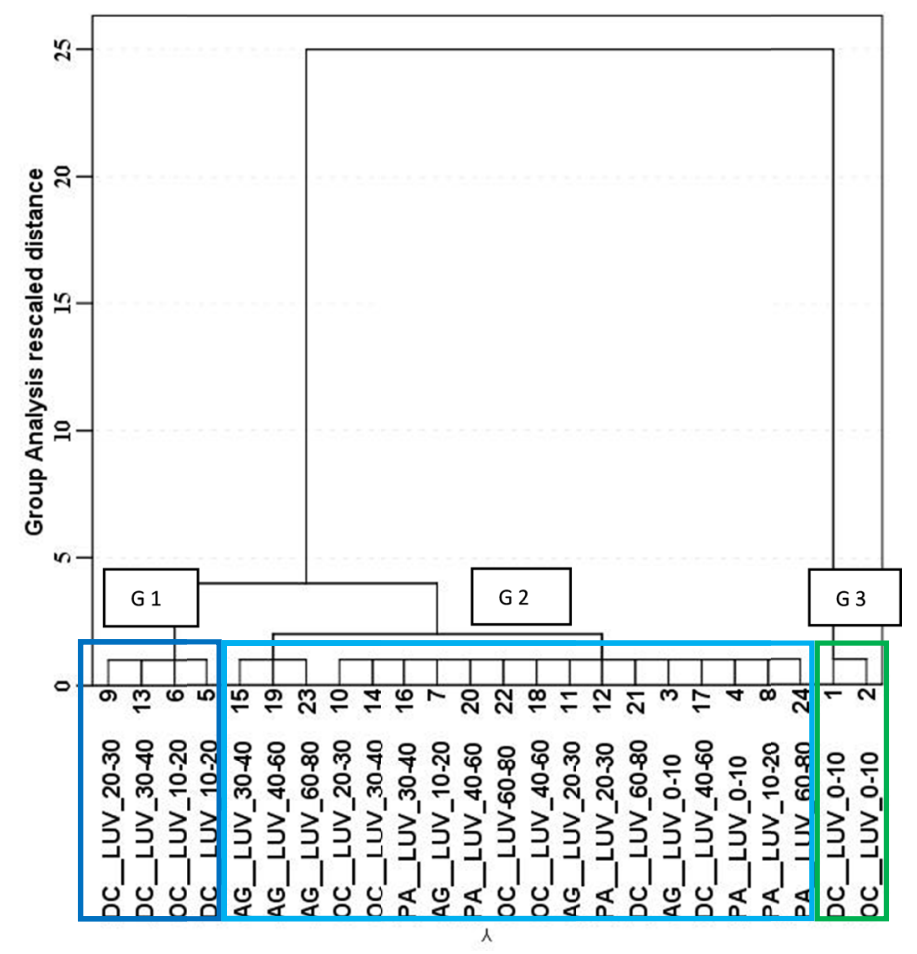

Figure 5. Dendrogram of the attributes, TOC and TN stock, for the four types of land use. Dense Caatinga (DC); Open Caatinga (OC); Pasture (PA); Agriculture (AG); Luvisol (LUV); Group (G)

Despite Groups 1 and 3 being characterised by the same types of land use (Figure 5), Group 3 showed higher mean values (Table 3 ), greater by $45.44 \%$ in relation to Group 1 . The values for each attribute were calculated based on the mean values for the TOC and TN content of each group between the types of land use. The highest values for ST.TOC (11.29 $\mathrm{Mg} \mathrm{ha}^{-1}$ ) were recorded in Group 3 (Table 3), followed by Group 1, with a mean value of $6.16 \mathrm{Mg}$ $\mathrm{ha}^{-1}$. Group 2 consisted of cases derived from the four types of land use and from all the studied layers, which resulted in a high coefficient of variation.

Table 3. Mean, minimum and maximum values, and standard deviation, for the attributes, stocks of TOC and TN, in a LUVISOL

\begin{tabular}{lllll}
\hline Attribute & Descriptive parameters & Group 1 & Group 2 & Group 3 \\
\hline ST.TOC $\left(\mathrm{Mg} \mathrm{ha}^{-1}\right)$ & Number of cases & 4 & 18 & 2 \\
& Mean \pm SD & $\mathbf{6 . 1 6} \pm 0.96$ & $\mathbf{4 . 4 8} \pm 2.03$ & $\mathbf{1 1 . 2 9} \pm 1.89$ \\
& Maximum & 7.78 & 9.62 & 13.18 \\
& Minimum & 5.28 & 2.24 & 11.39 \\
CV & 0.16 & 0.45 & 0.17 \\
\hline ST.TN $\left(\mathrm{Mg} \mathrm{ha}^{-1}\right)$ & Number of cases & 4 & 18 & 2 \\
& Mean \pm SD & $\mathbf{2 . 0 8} \pm 0.17$ & $\mathbf{2 . 0 6} \pm 0.90$ & $\mathbf{3 . 3 6} \pm 0.42$ \\
& Maximum & 2.38 & 4.4 & 4.08 \\
& Minimum & 1.96 & 1.02 & 3.25 \\
& CV & 0.08 & 0.44 & 0.13 \\
\hline
\end{tabular}

Note. ST.TOC: Total organic carbon stock; ST.TN: Total nitrogen stock; SD: Standard deviation; CV: Coefficient of variation. 
The ST.TN in the soil displayed similar behaviour to that seen for ST.TOC, i.e. the types of land use with higher values for ST.TOC also had the highest values for ST.TN (Table 3). The greatest values for ST.TN were found in Group 3, and the lowest in Groups 1 and 2. Group 1 consisted of DC and OC, and had mean values of $2.08 \mathrm{Mg} \mathrm{ha}^{-1}$, while Group 2 was formed by DC, OC, AG and PA, with a mean value of $2.06 \mathrm{Mg} \mathrm{ha}^{-1}$. Group 3 was composed of DC and OC, and had the highest mean values (Table 3 and Figure 5).

The highest values for ST.TOC (11.29 $\mathrm{Mg} \mathrm{ha}^{-1}$ ) and ST.TN (3.36 Mg ha ${ }^{-1}$ ) were found in DC and OC, and the lowest values (4.48 Mg ha ${ }^{-1}$ and $2.06 \mathrm{Mg} \mathrm{ha}^{-1}$ ) in DC, OC, AG and PA, especially in the deeper layers, where there is less carbon and nitrogen input to the soil.

\section{Discussion}

\subsection{Apparent Bulk Density}

Mean values for apparent density $\left(\mathrm{g} \mathrm{cm}^{-3}\right)$ tend to increase gradually (Figure 2$)$. These data are corroborated by Luciano et al. (2010) and Castro et al. (2012), who found an increase in bulk density with depth when evaluating areas of native forest; this can be explained by the lower input of organic material at increasing depth and density.

The higher apparent density of the soil in the area of PA in the 0-10 and 10-20 cm layers when compared to the area of DC is due to constant trampling by animals causing soil compaction (Costa et al., 2009); cattle grazing may increase soil compaction, due to the pressure exerted on the soil by the animals in areas of pasture (Don et al., 2011).

Higher values for apparent density in the $0-10,10-20,20-30,30-40$ and $60-80 \mathrm{~cm}$ layers were recorded in the area of AG when compared to DC. This result can be explained by the higher contribution of organic residue, which favours a greater amount of organic matter in the soil, since in the area of DC, higher levels of TOC and TN were found when compared to the other types of land use. In the area of DC, the effects of soil organic matter and vegetation result in a lower density.Soils with a larger amount of organic matter display low density due to the increase in organic matter from senescence of the root system in the subsoil. According to Anh et al. (2014), a low bulk density allows more organic carbon and total nitrogen to be stored in the soil, as these elements are mobilised in porous spaces in the soil matrix. The higher apparent density under agricultural management can be attributed to physical disturbance of the soil: compaction due to conventional preparation of the soil with the intensive use of machines (Barros, 2013).

The increase in the apparent density of the soil in the area of AG is related to both the quantity and quality of stable forms of organic matter, which are modified by cultivation practices (harrowing, seeding and machine traffic), due to increases in soil aeration causing burning of the organic matter.

\subsection{TOC Content}

The greatest levels of TOC were found in the surface layers, decreasing with depth in each type of land use under study. Similar behaviour was found by Aquino et al. (2017) when studying TOC levels in open (thinned) and dense (conserved) Caatinga. These results were possibly influenced by the accumulation and decomposition on the soil surface of the residue from plants and from tree pruning. Another relevant point is the input of organic residue (fine roots) from the cultivated areas, especially the area under pasture. Increases in herbaceous cover influence the soil-moisture dynamics, allowing greater deepening of the fine roots. This favours the input of carbon to the surface layers of the soil $(<30 \mathrm{~cm})$ from the organic residue of plant species with a $\mathrm{C} 4$ metabolic cycle (Aquino et al., 2017). Neumann-Cosel et al. (2011) report that the greater input of TOC on the soil surface comes from the accumulation of litter due to the low solubility of the organic residue.

The presence of greater levels of TOC in the soil in the areas of DC and OC may be influenced by the accumulation of litter (roots, branches, leaves, flowers and fruit) and the herbaceous stratum present in these areas. This may be due to the greater levels of organic carbon present in forest areas than in cultivated land, due to the input of residue to the soil surface, as previously argued by Bárcena et al. (2014). According to Barros et al. (2013) when changes occur in natural systems due to anthropogenic action (burning or conventional tillage), these changes directly affect the environmental balance, so that the amount of TOC and TN input to the system is usually smaller than the output.

The TOC content of the soil depends among other factors on the climate, on the content and nature of the clays, on land use, and on the management and drainage systems (Ebeling et al., 2013). According to Martins et al. (2010), water deficit is the main limiting factor in semi-arid environments. With the low rainfall typical of this region, the development of vegetation is limited, be it Caatinga, pasture or areas of agriculture. 


\subsection{TN Content}

The pattern for TN content was similar to that of the TOC content for each type of land use under study, reducing with increasing depth. This is due to $\mathrm{N}$ and $\mathrm{C}$ being components of organic matter and therefore closely associated. Since the surface layer of the soil is where the deposition of organic materials takes place with greater intensity, the highest values are concentrated on the surface. The greater levels of soil TN in the areas of DC and OC can be explained by the accumulation of litter (roots, branches, leaves, flowers and fruit) and the herbaceous stratum present in these areas (Aquino et al., 2017).

In this study, the levels of TN were low in relation to other studies, possibly because they were influenced by the climate conditions of the semi-arid region, where the water deficit, low humidity and high temperatures of the study region very likely interfere with microbial activity. The low accumulation of organic matter in semi-arid soils is a result of the limited production of plant biomass and rapid mineralisation during the rainy season, which means that most of the soils in the region have little nitrogen (Salcedo \& Sampaio, 2008). The replacement of nitrogen in the semi-arid region is mainly through the association of leguminous plants with rhizobia, which are able to fix atmospheric nitrogen (Freitas \& Sampaio, 2008).

\subsection{Stocks of TOC and TN}

The highest values found in Group 3 (Table 3) are related to the soil layer $(0-10 \mathrm{~cm})$ and land use. As the groups were formed based on the similarity and proximity between the types of land use, Groups 1 and 2 were characterised by the two similar or nearest groups, in addition, Group 1 included higher values than those of Group 2. Group 1 was characterised only by DC and OC, while Group 2 was characterised by DC, OC, AG and PA; this was due to the lower contribution of carbon and nitrogen in the deeper soil layers in DC and OC, and inadequate management in the areas of AG and PA. Since carbon and nitrogen are generally related to land use, their quantity tends to decrease with depth.

Analysing the behaviour of each group, it can be seen that the greatest values of ST.TOC and ST.TN were found in Group 3, formed by the areas of DC and OC. These results are related to the deposition of plant material by means of litter in the Caatinga (leaves, branches, roots and fruit), the presence of fine roots from the herbaceous stratum Aquino et al., 2017), and even by use intensity. Another relevant fact to be noted in Group 3, is that the mean values for land use in this group were found at a depth of $0-10 \mathrm{~cm}$; this is due to the higher organic matter content from the contribution of plant and organic residue in the surface layers of the soil, as was previously seen for the values of TOC and TN.

According to Kassa (2017), the presence of stocks of organic carbon and nitrogen in the higher soil layers of forests and in agroforestry can be explained by the continuous defoliation of the trees and shrubs. The stock of TOC and TN in soil under natural vegetation is largely determined by the input of carbon from plant residue (senescent material) or by incorporation from decomposition of the root system under pasture, and represents the dynamic balance between the addition of dead plant material and loss by decomposition or mineralisation (Faria et al., 2010).

The lower values of ST.TOC and ST.TN in Groups 1 and 2 in the areas of DC, OC, AG and PA, can mainly be attributed to the smaller contribution of organic residue to the lower layers of soil in DC and OC, however, in the areas of PA and AG, they may have been related to physical disturbances of the soil, more intensive use, greater export, deforestation, burning and soil turning, since the agricultural activities in these areas are developed through the intense use of deforestation, burning and short fallow periods.

It is therefore evident that anthropogenic interference tends to reduce the stocks of carbon and nitrogen in the soil, and that the removal of native vegetation no longer characterises the function of the forest as a carbon sink. The most exportable type of intensive land use, the removal of crop residue and post-harvest grazing, may have contributed to the low carbon storage in the soil and subsoil of cultivated land (Kassa, 2017).

In general, the results for type of land use show similar levels and stocks of TN and TOC, which points to $\mathrm{C}$ and $\mathrm{N}$ having similar dynamic processes. The changes that occurred in ST.TOC and ST.TN for type of land use were related to soil management and depth; depending on the management system, the levels and stocks of TOC and TN can remain the same, increase, or decrease in relation to the natural system. From the results obtained for the types of land use in this study, no effects were seen on the levels and stocks of TOC or TN in the deeper layers of the soil.

\section{Conclusions}

Changes in land use in the SDTF had an effect on ST.TOC and ST.TN. It is therefore necessary to adopt strategies and strengthen conservation practices in areas of agricultural and pasture, and reduce the process of degradation, 
leading an increase in the process of recovery in these areas. Such action will reduce the loss of $\mathrm{C}$ and $\mathrm{N}$, and increase the levels and stocks of TOC and TN.

The levels and stocks of TOC and TN in the SDTF vary according to the types of land use under study. Depending on the management system, the levels and stocks of TOC and TN can remain the same, increase, or decrease in relation to the natural system.

\section{Acknowledgements}

The authors wish to thank the Brazilian government support agency Council for Scientific and Technological Development (CNPq), the Federal Agency for the Support and Evaluation of Postgraduate Education (CAPES) and the Support Foundation for Scientific and Technological Development of Ceará (FUNCAP) for their financial support and productivity grants.

\section{References}

Andrade, E. M., Sena, M. G. T., Silva, A. G. R., Perreira, F. J. S., \& Lopes, F. B. (2016). Uncertainties of the rainfall regime in a tropical semi-arid region: The case of the State of Ceará. Revista Agro@mbiente, 10, 88-95. https://doi.org/10.18227/1982-8470ragro.v10i2.3500

Anh, P. T. Q., Gomi, T., Macdonald, L. H., Mizugaki, S., Khoa, P. V., \& Furuichi, T. (2014). Links between land use, macronutrient levels and soil erosion in northern Vietnam: A plot-scale study. Geoderma, 232-234, 352-362. https://doi.org/10.1016/j.geoderma.2014.05.011

Aquino, D. N., Andrade, E. M., Castanho, A. D. A., Júnior, L. R. P., \& Palácio, H. A. Q. (2017). Belowground Carbon and Nitrogen on a Thinned and Un-Thinned Seasonally Dry Tropical Forest. American Journal of Plant Science, 8, 2158-2750. https://doi.org/10.4236/ajps.2017.89140

Araújo Filho, J. A. (2013). Caracterização física do Semiárido Nordestino. Manejo pastoril sustentável da Caatinga. Projeto Dom Helder Câmara, Recife, PE.

Bárcena, T. G., Kiaer, L. P., Vesterdal, L., Stefándóttir, H. M., Gundersen, P., \& Sigurdsson, B. D. (2014). Soil carbon stock change following afforestation in northern Europe: A meta-analysis. Global Change Biology, 20, 2393-2405. https://doi.org/10.1111/gcb.12576

Barros, J. D. S., Chaves, L. H. G., Chaves, I. B., Férias, C. H. A., \& Perreira, W. E. (2013). Estoque de carbono e nitrogênio em sistemas de manejo do solo, nos tabuleiros costeiros paraibanos. Revista Caatinga, 26, 35-42.

Black, C. A., Evans, D. D., Ensminger, L. E., White, J. L., \& Clark, F. E. (1965). Methods of soil analysis. American Society of Agronomy (2nd ed., p. 770). Madison, Winscousin.

Brasil. (2010). Ministério da Ciência e Tecnologia. Segundo inventario brasileiro de emissões e remoções de gases de efeito estufa: Emissões de gases de efeito estufa no setor uso da terra, mudanças do uso da terra. Brasília.

Carvalho, J. L. N., Cerri, C. E. P., Feigl, B. J., Píccolo, M. C., Godinho, V. P., \& Cerri, C. C. (2009). Carbon sequestration in agricultural soils in the Cerrado region of the Brazilian Amazon. Soil and Tillage Research, 103, 342-349. https://doi:10.1016/j.still.2008.10.022

Castro, M. A., Cunha, F. F., Lima, S. F., Paiva, V. B., Leite, D. A. P., \& Magalhães, F. F. (2012). Atributos físico-hídricos do solo ocupado com pastagem degradada e floresta nativa no Cerrado Sul-Mato Grossense. Brazilian Geographical Journal: Geosciences and Humanities Research Medium, 3, 498-512.

Costa, O. V., CantaruttI, R. B., Fontes, L. E. F., Costa, L. M. da, Nacif, P. G. S., \& Farias, J. C. (2009). Estoque de carbono do solo sob pastagem em área de Tabuleiro Costeiro no sul da Bahia. Revista Brasileira de Ciencia do Solo, 33, 1137-1145. https://doi.org/10.1590/S0100-06832009000500007

Demessie, A., Singh, B. R., \& Lal, R. (2013). Soil carbon and nitrogen stocks under chronosequence of farm and traditional agroforestry land uses in Gambo District, Southern Ethiopia. Nutrient cycling in Agroecosystems, 95, 365-375. https://doi:10.1007/s10705-013-9570-0

Don, A., Schumacher, J., \& Freibauer, A. (2011). Impact of tropical land-use change on soil organic carbon stocks-A meta-analysis. Global Change Biology, 17, 1658-1670. https://doi.org/10.1111/j.1365-2486. 2010.02336.x

Ebeling, A. G., Anjos, L. H. C., Pereira, M. G., Valladares, G. S., \& Pérez, D. V. (2013). Substâncias húmicas e suas relações com o grau de subsidência em Organossolos de diferentes ambientes de formação no Brasil. Revista Ciência Agronômica, 44, 225-233. https://doi.org/10.1590/S1806-66902013000200003 
Ellert, B. H., Janzen, H. H., \& Mcconkey, B. G. (2001). Measuring and comparing soil carbon storage. In R. Lal, J. M. Kimble, R. F. Follet, \& B. A. Stewart (Eds.), Assessment methods for soil carbon (pp. 131-146). Lewis imprint of the CRC Press.

EMBRAPA (Empresa Brasileira de Pesquisa Agropecuária). (2013). Sistema Brasileiro de Classificação de Solos (3rd ed., p. 353). Brasília.

Faria, A. F. G., Santos, A. C., Santos, T. M., \& Filho, F. B. (2010). Influência do manejo do solo nas propriedades químicas e físicas em topos sequência na bacia do rio Araguaia, estado do Tocantins. Revista Brasileira de Ciência do Solo, 34, 517-524. https://doi.org/10.1590/S0100-06832010000200025

Freitas, A. D. S., \& Sampaio, E. V. S. B. (2008). Fixação biológica do $\mathrm{N}_{2}$ em leguminosas arbóreas da Paraíba e de Pernambuco. In R. S. C. Menezes, E. V. S. B. Sampaio, \& I. H. Salcedo (Eds.), Fertilidade do solo e produção de biomassa no semi-árido (pp. 27-46). Recife: Ed. Universitária UFPE.

Ghommem, M., Hajj, M. R., \& Puri, I. K. (2012). Influence of natural and anthropogenic carbon dioxide sequestration on global warming. Ecological Modelling, 235-236, 1-7. https://doi.org/10.1016/j.ecolmodel. 2012.04.005

Kassa, H., Dondeyne, S., Poesen, J., Frankl, A., \& Nyssen, J. (2017). Impact of deforestation on soil fertility, soil carbon and nitrogen stocks: The case of the Gacheb catchment in the White Nile Basin, Ethiopia. Ecosystems and Environment, 247, 20. https://doi.org/10.1016/j.agee.2017.06.034

Li, H., \& Yang, X. (2014). Temperate dryland vegetation changes under a warming climate and strong human intervention. With a particular reference to the district Xilin Gol, Inner Mongolia, China. Catena, 119, 9-20. https://doi.org/10.1016/j.catena.2014.03.003

Luciano, R. V., Bertol, I., Barbosa, F. T., Kurtz, C., \& Fayd, J. A. (2010). Propriedades físicas e carbono orgânico do solo sob plantio direto comparado a mata natural, num Cambissolo Háplico. Revista de Ciências Agrovetetinárias, 9, 09-19.

Martins, C. M., Galindo, I. C. L., Souza, E. R., \& Poroca, H. A. (2010). Atributos químicos e microbianos do solo de áreas em processo de desertificação no semiárido de Pernambuco. Revista Brasileira de Ciência do Solo, 34, 1883-189. http://dx.doi.org/10.1590/S0100-06832010000600012

MCTI (Ministério da Ciência, Tecnologia e Inovação). (2014). Estimativas anuais de emissões de gases de efeito estufa no Brasil (2nd ed.).

MMA/IBAMA (Ministério doo Meio Ambiente/Instituto Brasileiro do Meio Ambiente e dos Recursos Naturais). (2014). Monitoramento do desmatamento nos biomas brasileiros por satélite acordo de cooperação técnica MMA/IBAMA: monitoramento do bioma Caatinga (p. 46). Brasília: MMA.

Neumann-Cosel, L., Zimmermann, B., Hall, S. J., Breugel, V., \& Michiel, E. H. (2011). Soil carbon dynamics under young tropical secondary forest on former pastures: A case study from Panama. Forest Ecology and Management, 261, 1625-1633. https://doi.org/10.1016/j.foreco.2010.07.023

Perreira, O. J., \& Andrade, E. M. (2016). Alternativas de convivência com o semiárido. In E. M. Andrade, O. J. Perreira, \& F. É. Dentas (Eds.), Semiárido e Manejo dos Recursos Naturais. Fortaleza-CE.

Rosendo, J. S., \& Rosa, R. (2012). Comparação do estoque de C estimado em pastagens e vegetação nativa de Cerrado. Sociedade \& Natureza, 24, 359-376. https://doi.org/10.1590/S1982-45132012000200014

Sacramento, J. A. A. S., Araújo, A. C. M., Escobar, M. E. O., Xavier, F. A. S., Cavalcante, A. C. R., \& Oliveira, T. S. (2013). Soil carbon and nitrogen stocks in traditional agricultural and agroforestry systems in the semiarid region of Brazil. Revista Brasileira de Ciência do Solo, 37, 784-795. https://doi.org/10.1590/S010006832013000300025

Salcedo, I. H., \& Sampaio, E. V. S. B. (2008). Matéria orgânica do solo no Bioma Caatinga. In G. de A. Santos (Ed.), Fundamentos da matéria orgânica do solo (p. 636). Ecossistemas tropicais e subtropicais.

Sampaio, E. V. S. B., \& Costa, T. L. (2011). Estoques e fluxos de carbono no semiárido nordestino: Estimativas preliminares. Revista Brasileira de Geografia Física, 6, 1275-1291.

Santos, H. G., Jacomine, P. K., T., Anjos, L. H. C., Oliveira, V. A., Lumbreras, J. F., Coelho, M. R., \& Oliveira, J. B. (2013). Sistema Brasileiro de Classificação de Solos (3rd ed., p. 353). Brasília, DF: EMBRAPA. 
Silva, R. F., Soares, C. P. B., Jacovine, L. A. G., Silva, M. L., Leite, H. G., \& Silva, G. F. (2008). Projeção do estoque de carbono e análise da geração de créditos em povoamentos de eucalipto. Revista Árvore, 32 , 979-992. https://doi.org/10.1590/S0100-67622008000600003

Souza, B. V. (2012). Estoque de carbono em diferentes fisionomias de Caatinga do Seridó da Paraíba (55f. Dissertação (Mestrado em Ciências Florestais), Centro de Saúde e Tecnologia Rural, Universidade Federal de Campina Grande).

Yeomans, J. C., \& Bremner, J. M. (1998). A rapid and precise method for routine determination of organic carbon in soil. Communications in Soil Science and Plant Analysis, 19, 1467-1476. https://doi.org/10.1080/0010 3628809368027

\section{Copyrights}

Copyright for this article is retained by the author(s), with first publication rights granted to the journal.

This is an open-access article distributed under the terms and conditions of the Creative Commons Attribution license (http://creativecommons.org/licenses/by/4.0/). 